\title{
Effects of dietary amylase and sucrose on productivity of cows fed low-starch diets
}

\author{
C. F. Vargas-Rodriguez, ${ }^{*}$ M. Engstrom, $†$ E. Azem,‡ and B. J. Bradford ${ }^{* 1}$ \\ *Department of Animal Sciences and Industry, Kansas State University, Manhattan 66506 \\ †DSM Nutritional Products Inc., Parsippany, NJ 07054 \\ fDSM Nutritional Products Ltd., 4002 Basel, Switzerland
}

\section{ABSTRACT}

Recent studies have observed positive effects of both sucrose and exogenous amylase on the productivity of dairy cattle. Our objective was to evaluate direct effects and interactions of amylase and sucrose on dry matter intake (DMI), milk production, and milk components. Forty-eight multiparous Holstein cows between 70 and $130 \mathrm{~d}$ in milk were randomly assigned to each of 4 pens (12 cows/pen). Pens were randomly assigned to treatment sequence in a $4 \times 4$ Latin square design, balanced for carryover effects. Treatment periods were $28 \mathrm{~d}$, with $24 \mathrm{~d}$ for diet adaptation and $4 \mathrm{~d}$ for sample and data collection. The treatments were a control diet $(36 \%$ $\mathrm{NDF}$ and $21 \%$ starch), the control diet with amylase [0.5 g/kg of DM; Ronozyme RumiStar 600 (CT); DSM Nutritional Products Ltd., Basel, Switzerland], a diet with sucrose replacing corn grain at $2 \%$ of $\mathrm{DM}$, and the sucrose diet with amylase $(0.5 \mathrm{~g} / \mathrm{kg}$ of $\mathrm{DM})$. All data were analyzed with mixed models, including the fixed effects of sugar, amylase, and their interaction, and the random effects of period and pen. Milk data included the random effects of cow nested within pen and pen $x$ period to provide the error term for the pen-level analysis. Dry matter intake was not affected by treatments. Milk yield and milk composition were not altered by the inclusion of sucrose or amylase; however, a tendency for an amylase $\times$ sucrose interaction was observed for milk protein content, reflecting slightly lower milk protein concentrations for amylase and sucrose treatments (3.00 and $2.99 \pm 0.03 \%$ ) compared with the control and amylase + sucrose treatments (3.02 and $3.03 \pm$ $0.03 \%)$. Solids-corrected and fat-corrected milk yields were not significantly altered by treatment, although the direct effect of amylase approached significance for both variables, suggesting possible small increases with amylase supplementation $(\sim 0.5 \mathrm{~kg} / \mathrm{d})$. Feed efficiency (energy-corrected milk divided by dry matter intake) numerically increased with either amylase $(1.57 \pm 0.12)$

Received December 17, 2013.

Accepted March 15, 2014

${ }^{1}$ Corresponding author: bbradfor@ksu.edu or sucrose $(1.60 \pm 0.12)$ treatment, but the combination of the 2 resulted in feed efficiency similar to the control treatment (both $1.50 \pm 0.12$ ). The inclusion of amylase or sucrose did not affect DMI, productivity, or feed efficiency in mid-lactation cows fed low-starch, high-fiber diets.

Key words: sugar, enzyme, lactation

\section{INTRODUCTION}

In addition to the requirements for maintenance and growth, dairy cows face higher demands for nutrients during lactation. Carbohydrates are used as the main source of energy, typically providing over half of the energy in livestock diets (Nafikov and Beitz, 2007). Most diets for lactating dairy cattle in the United States contain 25 to 30\% starch (Ellis et al., 2011; DeVries and Gill, 2012; Golder et al., 2012). The high ruminal degradability of starch provides substrate to support VFA production and microbial growth and, therefore, microbial enzyme production and microbial $\mathrm{CP}$ production. This enzymatic degradation is crucial to whole-body metabolism because glucose precursors and other fuels are generated through it for host-animal metabolism (Lemosquet et al., 2009).

Another source of energy in ruminant rations is sugar, short-chain carbohydrates that are rapidly degradable in the rumen (Miller et al., 1969; Masuda et al., 1999). Sugar has been used to replace some starch due to the increasing demand and price of starch sources (Ranathunga et al., 2010; Bradford and Mullins, 2012). The benefits of using sugars rely on their digestibility in the rumen. Unlike starch and structural carbohydrates, sugar molecules require only minimal enzymatic activity (cleavage of disaccharide bonds) before cellular uptake and metabolism, making it easier for microbes to degrade them (Golder et al., 2012). Microbes can thus use sugars faster as fuels and convert them to VFA that can be absorbed by the host animal in a short period of time (Nafikov and Beitz, 2007). It is also possible that sugars do not affect ruminal $\mathrm{pH}$; indeed, they could help prevent drastic decreases in $\mathrm{pH}$ and promote the 
digestibility of fiber (Penner et al., 2007; Penner and Oba, 2009; Firkins, 2010). This positive influence could minimize acidosis problems and limit the risk of milk fat depression. Beneficial effects have been observed when sugar was included from 2 to $5 \%$ of the diet on a DM basis (Broderick and Radloff, 2004; Martel et al., 2011).

The inclusion of exogenous amylase in diets for high-producing cows is designed to enhance the utilization of carbohydrates in feeds. In many nonruminant animals, the salivary glands secrete amylase to begin breaking down starch as soon as food enters the mouth. Ruminants do not have salivary amylase (McDougall, 1948); the microbial population in the rumen is largely responsible for the degradation of starch.

The addition of exogenous amylase has been evaluated primarily as a method to increase ruminal starch degradability, but the literature suggests that amylase may improve productivity of lactating cows independent of effects on total-tract starch digestion (DeFrain et al., 2005; Cabrita et al., 2007; Ferraretto et al., 2011). In fact, one of the most consistent responses to exogenous amylase is an increase in NDF digestibility (Bowman et al., 2002; Gencoglu et al., 2010). Recent studies have suggested that inclusion of sugar sources to reach dietary sugar concentrations of 5 to $8 \%$ may also promote fiber digestion (Broderick et al., 2008; Firkins, 2010). These findings suggest that sugars, whether provided in the diet or produced by the activity of exogenous amylase in the rumen, may promote the growth of fiber-digesting bacteria and thereby increase fiber digestibility.

We hypothesized that dietary amylase and sucrose could improve fiber digestion and, in turn, the productivity of lactating cows. However, because of similar proposed modes of action, we also hypothesized that the effects of added sugar and amylase may not be additive. The specific objective of the present study was to evaluate DMI, milk production, and milk components in lactating dairy cows fed exogenous amylase, sucrose, or both in the context of a low-starch diet.

\section{MATERIALS AND METHODS}

The experimental procedures for this experiment were approved by the Institutional Animal Care and Use Committee at Kansas State University (Manhat$\tan )$.

\section{Design and Treatments}

Forty-eight Holstein cows from 70 to 130 DIM (101 \pm 22 DIM; mean $\pm \mathrm{SD}$ ) from Kansas State University Dairy Cattle Teaching and Research Unit were blocked by parity $(1.70 \pm 0.88$ lactations $)$ and stage of lactation. Within block, cows were randomly assigned to 1 of 4 pens (12 cows/pen). Pens were then randomly assigned to treatment sequence in a $4 \times 4$ Latin square design, balanced for carryover effects. Treatments (Table 1) were (1) control diet, (2) control diet with amylase added at $0.5 \mathrm{~g} / \mathrm{kg}$ of DM, (3) a diet with sucrose replacing corn grain at $2 \%$ of $\mathrm{DM}$, and (4) the sucrose diet with amylase added at $0.5 \mathrm{~g} / \mathrm{kg}$ of DM. The amylase used was Ronozyme RumiStar (lots AUN01024 and AUN01028; DSM Nutritional Products Ltd., Basel, Switzerland), with a declared amylase activity of 600 kilo novo units $(\mathbf{K N U}) / \mathrm{g}$. The diets were formulated to provide $35 \% \mathrm{NDF}, 16 \% \mathrm{CP}, 3 \%$ ether extract, $2.65 \mathrm{Mcal}$ of ME/ $\mathrm{kg}$ of DM, $3.12 \mathrm{~kg}$ of MP, and micronutrients to meet predicted requirements for cows with a mean BW of $635 \mathrm{~kg}$, producing $45 \mathrm{~kg}$ of milk per day with a fat content of $3.50 \%$, consuming 26.1 $\mathrm{kg}$ of DM/d (NRC, 2001). Dry components of the diets (not including cottonseed) were blended into premixes approximately $2 \mathrm{wk}$ before the start of the study, and samples were submitted to DSM Nutritional Products Analytical Services (Basel, Switzerland) for determination of amylase activity (Jung and Vogel, 2008). Each diet was delivered as a TMR, and corn silage DM was determined twice weekly to adjust its inclusion rate. Cows were fed once daily for ad libitum intake and milked 3 times daily throughout the experiment. Treatment periods were $28 \mathrm{~d}$, with $24 \mathrm{~d}$ for diet adaptation and $4 \mathrm{~d}$ for sample and data collection.

\section{Sample and Data Collection}

The amounts of feed offered and refused were measured for each pen daily to determine DMI. During the final $4 \mathrm{~d}$ of each period, samples of orts and each feed ingredient were collected daily and composited by period for analysis. Total mixed ration samples were collected daily and analyzed for particle size on the first and last days of each collection period using the Penn State Particle Separator (The Pennsylvania State University, University Park; Lammers et al., 1996; Kononoff et al., 2003). Milk yield was recorded for each cow daily. Milk samples were collected at each milking during the 4-d collection periods. Body condition scores were determined by 2 trained investigators at the beginning of period 1 and at the end of each period using a 1 to 5 scale (Wildman et al., 1982).

\section{Sample Analyses}

All milk samples were analyzed for concentrations of fat, lactose, true protein (B-2000 Infrared Analyzer; Bentley Instruments Inc., Chaska, MN), MUN (MUN 
spectrophotometer; Bentley Instruments Inc.), and somatic cells (SCC 500; Bentley Instruments Inc.; Heart of America DHIA, Manhattan, KS). Energy-corrected milk yield was calculated using the following formula: $0.327 \times$ milk yield $+12.86 \times$ fat yield $+7.65 \times$ protein yield (Dairy Records Management Systems, 2011).

Feed ingredient, TMR, and orts samples were dried in a $55^{\circ} \mathrm{C}$ forced-air oven for $72 \mathrm{~h}$ to determine $\mathrm{DM}$ content. To prepare the samples for subsequent analyses, samples were ground in a Wiley mill (Arthur H. Thomas Co., Philadelphia, PA) through a 1-mm screen and then composited by period. To express all the nutrients on a common DM basis, the samples were dried at $105^{\circ} \mathrm{C}$ in a forced-air oven for more than $8 \mathrm{~h}$. Ash concentration was determined after $5 \mathrm{~h}$ of combustion at $500^{\circ} \mathrm{C}$ in a muffle furnace. The concentration of NDF was determined in the presence of sodium sulfite and amylase with an Ankom Fiber Analyzer (Ankom Technology, Fairport, NY; Van Soest et al., 1991). Crude protein concentration was determined by combustion and detection of $\mathrm{N}_{2}$ (Leco Analyzer; Leco Corp., St. Joseph, MI). Crude fat concentration was determined by ether extraction (AOAC International, 2000; method 920.9). Total sugars were quantified in a commercial laboratory by incubation with invertase followed by measurement of reducing sugars (Lane and Eynon, 1923). Starch was determined by $\alpha$-amylase and glucoamylase digestion, followed by colorimetric glucose quantification with a commercial kit (Autokit Glucose; Wako Chemicals USA, Richmond, VA). All analyses were performed in duplicate.

\section{Statistical Analysis}

Two cows were removed from the study for health reasons unrelated to treatments; one in period 1 and the other in period 4. Feed intakes were determined per pen based upon the number of cows present in each pen. All data were analyzed with mixed models, including the fixed effects of sugar, amylase, and their interaction, and the random effects of period and pen. Milk data included the random effects of cow nested within pen and pen $\times$ period to provide the error term for the pen-level analysis. Denominator degrees of freedom were checked to verify that pen was treated as the experimental unit for all variables. Data were analyzed using the REML procedure of JMP (version 8.0; SAS Institute Inc., Cary, NC). Significance of the treatments was declared at $P<0.05$ and tendencies at $P<0.10$.

\section{RESULTS}

The enzymatic activity of amylase in the grain premixes was evaluated at the beginning of the study. Based
Table 1. Ingredient composition (\% of diet DM) of diets

\begin{tabular}{|c|c|c|}
\hline \multirow[b]{2}{*}{ Ingredient } & \multicolumn{2}{|c|}{ Treatment $^{1}$} \\
\hline & Control & Sucrose \\
\hline Corn silage & 38.1 & 38.1 \\
\hline Alfalfa hay & 28.2 & 28.2 \\
\hline Wet corn gluten feed ${ }^{2}$ & 10.2 & 10.1 \\
\hline Ground corn & 8.22 & 6.25 \\
\hline Sucrose & - & 1.93 \\
\hline Whole cottonseed & 5.10 & 5.10 \\
\hline Expeller soybean meal ${ }^{3}$ & 6.10 & 6.17 \\
\hline Soybean meal $(48 \% \mathrm{CP})$ & 2.02 & 2.05 \\
\hline Micronutrient premix ${ }^{4}$ & 2.09 & 2.12 \\
\hline
\end{tabular}

${ }^{1}$ Each diet was tested with and without amylase (RumiStar; DSM Ltd., Basel, Switzerland) added.

${ }^{2}$ SweetBran (Cargill Inc., Blair, NE).

${ }^{3}$ Soy Best (Grain States Soya, West Point, NE).

${ }^{4}$ Premix consisted of $57 \%$ limestone, $16 \%$ Menhaden fish meal, $7.6 \%$ magnesium oxide, $7.2 \%$ vitamin E premix (44 IU/g), $4.5 \%$ selenium premix (600 mg of Se/kg), 3.6\% 4-Plex (Zinpro Corp., Eden Prairie, MN; contained $2.58 \% \mathrm{Zn}, 1.48 \% \mathrm{Mn}, 0.90 \% \mathrm{Cu}, 0.18 \%$ Co, $8.21 \%$ Met, and $3.80 \%$ Lys), $2.2 \%$ trace mineral salt (contained $98.5 \% \mathrm{NaCl}, 0.35 \%$ $\mathrm{Zn}, 0.2 \% \mathrm{Fe}, 0.2 \% \mathrm{Mn}, 0.03 \% \mathrm{Cu}, 0.007 \% \mathrm{I}$, and $0.005 \% \mathrm{Co}), 2.2 \%$ vitamin A premix $(30 \mathrm{IU} / \mathrm{g})$, and $0.45 \%$ vitamin $\mathrm{D}$ premix $(30 \mathrm{IU} / \mathrm{g})$.

on these analyses, amylase activity was $405 \mathrm{KNU} / \mathrm{kg}$ for the amylase TMR and $351 \mathrm{KNU} / \mathrm{kg}$ for the amylase + sucrose TMR. These values are in the range targeted by other authors who used the same type of enzyme (300-400 KNU/kg; Gencoglu et al. 2010; Weiss et al. 2010; Ferraretto et al., 2011).

The nutrient composition and particle size of experimental diets fed during the study are presented in Table 2. By design, concentrations of macronutrients were similar across treatments, with the primary difference being the replacement of some starch with sugar. The total dietary concentrations of sugar were 6.3 and $6.8 \%$ for the diets without sucrose, and 8.4 and $8.6 \%$ (DM basis) for the sucrose treatments. The starch content of the diets did not surpass $21.5 \%$ of DM and was slightly lower in the sucrose treatments. Table 2 also shows the particle size distributions of the TMR as determined using the Penn State Particle Separator. The top sieve $(>1.9 \mathrm{~cm})$ retained around $20 \%$ of DM for all the treatments, which demonstrated that the diets had high concentrations of effective fiber.

The effects of diets on DMI, milk components, and milk production are detailed in Table 3 . The addition of sucrose or exogenous amylase, or both, did not generate significant differences $(P>0.10)$ for DMI or milk yield. Among milk components, a tendency for an amylase $\times$ sucrose interaction was observed for milk protein content $(P=0.06)$, reflecting slightly lower milk protein concentrations for amylase and sucrose treatments compared with the control and amylase + sucrose treatments. This interaction was not observed for milk protein yield; the direct amylase effect approached 
Table 2. Nutritional composition (\% of DM, unless otherwise noted) and particle size characterization of the diets

\begin{tabular}{|c|c|c|c|c|}
\hline \multirow[b]{2}{*}{ Item } & \multicolumn{2}{|c|}{ Control } & \multicolumn{2}{|c|}{ Amylase } \\
\hline & Control & Sucrose & Control & Sucrose \\
\hline \multicolumn{5}{|l|}{ Composition } \\
\hline DM, \% as-fed & 57.0 & 55.6 & 54.7 & 56.8 \\
\hline $\mathrm{OM}$ & 91.5 & 91.6 & 91.3 & 91.4 \\
\hline $\mathrm{Ash}^{1}$ & 8.5 & 8.4 & 8.7 & 8.6 \\
\hline $\mathrm{CP}$ & 16.5 & 16.5 & 16.5 & 16.3 \\
\hline $\mathrm{NDF}$ & 35.6 & 35.2 & 35.4 & 34.9 \\
\hline Starch & 21.4 & 20.6 & 21.4 & 20.9 \\
\hline Sugars $^{2}$ & 6.3 & 8.4 & 6.8 & 8.6 \\
\hline Ether extract & 3.2 & 3.0 & 3.2 & 3.0 \\
\hline \multicolumn{5}{|l|}{ Particle size ${ }^{3}$} \\
\hline Top, $\%$ & 20.3 & 20.2 & 21.4 & 21.1 \\
\hline Middle, \% & 36.3 & 35.3 & 33.5 & 33.9 \\
\hline Bottom, \% & 27.0 & 27.8 & 28.1 & 27.6 \\
\hline Pan, $\%$ & 16.4 & 16.7 & 17.0 & 17.4 \\
\hline
\end{tabular}

${ }^{1}$ Formulated mineral concentrations in control diet: $1.84 \% \mathrm{~K}, 1.04 \% \mathrm{Ca}, 0.37 \% \mathrm{P}, 0.21 \% \mathrm{~S}, 0.20 \% \mathrm{Cl}, 0.07 \%$ $\mathrm{Na}, 146 \mathrm{mg}$ of Fe/kg, $51.5 \mathrm{mg}$ of $\mathrm{Zn} / \mathrm{kg}, 48.7 \mathrm{mg}$ of I/kg, $36.4 \mathrm{mg}$ of Mn/kg, $12.1 \mathrm{mg}$ of Cu/kg, $2.91 \mathrm{mg}$ of Se/ $\mathrm{kg}$, and $1.52 \mathrm{mg}$ of $\mathrm{Co} / \mathrm{kg}$.

${ }^{2}$ Determined by invertase (Lane and Eynon, 1923).

${ }^{3}$ Top sieve: $>1.9 \mathrm{~cm}$; middle sieve: 0.31 to $1.9 \mathrm{~cm}$; bottom sieve: 0.18 to $0.31 \mathrm{~cm}$; pan: $<0.18 \mathrm{~cm}$ (Kononoff et al., 2003).

significance for this variable $(P=0.11)$, reflecting marginally greater protein yield $(20 \mathrm{~g} / \mathrm{d})$ when amylase was included in the diets. Likewise, SCM and FCM yield variables were not significantly altered by treatment, although the direct effect of amylase approached significance in both cases (both $P=0.13$ ), suggesting possible small increases with amylase supplementation $(\sim 0.5 \mathrm{~kg} / \mathrm{d})$.

Body condition score did not differ across treatments at the beginning of the study, and the change in BCS during the 28 -d periods was not affected by amylase, sucrose, or their interaction (Table 3). Production efficiency (ECM/DMI) was not significantly altered by treatment; although either amylase or sucrose alone numerically increased efficiency, the combination of the 2 resulted in feed efficiency equivalent to the control treatment.

\section{DISCUSSION}

Some fiber-digesting bacteria (Butyrivibrio fibrisolvens, Fibrobacter succinogenes, and Prevotella rumi-

Table 3. Sucrose and amylase effects on intake, productivity, and milk composition of lactating dairy cows fed low-starch diets

\begin{tabular}{|c|c|c|c|c|c|c|c|c|}
\hline Item & \multicolumn{2}{|c|}{ Control } & \multicolumn{2}{|c|}{ Amylase } & SEM & \multicolumn{3}{|c|}{$P$-value } \\
\hline DMI, $\mathrm{kg} / \mathrm{d}$ & 23.5 & 22.2 & 22.9 & 23.9 & 1.3 & 0.42 & 0.89 & 0.11 \\
\hline Milk fat, \% & 3.67 & 3.69 & 3.66 & 3.72 & 0.092 & 0.70 & 0.22 & 0.56 \\
\hline Milk true protein, $\%$ & 3.02 & 2.99 & 3.00 & 3.03 & 0.026 & 0.42 & 0.88 & 0.06 \\
\hline Milk lactose, \% & 4.78 & 4.77 & 4.78 & 4.77 & 0.028 & 0.90 & 0.19 & 0.95 \\
\hline SCC linear score & 2.08 & 2.01 & 2.34 & 1.97 & 0.27 & 0.53 & 0.21 & 0.38 \\
\hline Fat yield, $\mathrm{kg} / \mathrm{d}$ & 1.25 & 1.24 & 1.26 & 1.27 & 0.060 & 0.16 & 0.88 & 0.49 \\
\hline Protein yield, $\mathrm{kg} / \mathrm{d}$ & 1.03 & 1.01 & 1.04 & 1.04 & 0.030 & 0.11 & 0.28 & 0.35 \\
\hline Lactose yield, $\mathrm{kg} / \mathrm{d}$ & 1.64 & 1.62 & 1.67 & 1.64 & 0.070 & 0.21 & 0.27 & 0.91 \\
\hline $\mathrm{SCM},{ }^{1} \mathrm{~kg} / \mathrm{d}$ & 32.3 & 32.0 & 32.7 & 32.7 & 1.30 & 0.13 & 0.49 & 0.64 \\
\hline $\mathrm{ECM},{ }^{2} \mathrm{~kg} / \mathrm{d}$ & 35.2 & 34.8 & 35.6 & 35.6 & 1.30 & 0.13 & 0.51 & 0.59 \\
\hline BCS change $(/ 28 \mathrm{~d})$ & 0.013 & -0.012 & -0.010 & -0.116 & 0.045 & 0.17 & 0.18 & 0.37 \\
\hline
\end{tabular}

${ }^{1}$ Solids-corrected milk yield $=(12.3 \times$ fat yield $)+(6.56 \times$ SNF yield $)-(0.0752 \times$ milk yield $)($ Tyrrell and Reid, 1965$)$.

${ }^{2}$ Energy-corrected milk yield $=(0.327 \times$ milk, $\mathrm{kg})+(12.86 \times$ milk fat, $\mathrm{kg})+(7.65 \times$ milk protein, $\mathrm{kg})($ Dairy Records Management Systems, 2013) 
nicola) are known to use sources of rapidly available energy to begin the process of cell wall degradation (Miron et al., 2002). They usually use starch when this nutrient is available; however, they have to compete against amylolytic bacteria (Streptococcus bovis, Butyrivibrio fibrisolvens, Bacteroides ruminicola, and Selenomonas ruminantium), which grow more aggressively in the presence of starch. End products of starch fermentation can alter the ruminal environment (by causing a higher rate of organic acid production and lower ruminal $\mathrm{pH}$ ), thus affecting the conditions for fibrolytic microorganisms (Huntington, 1997; Zebeli et al., 2012). This scenario led to the suggestion that provision of sugar may bypass some of the competitive disadvantages of fibrolytic bacteria (Oba, 2011).

The results of the current study revealed no production responses to dietary amylase or sucrose. The DMI was similar across treatments, which is in contrast with the findings of Klingerman et al. (2009), who showed increased DMI when an extract of Aspergillus oryzae with $\alpha$-amylase activity between 94 and 28,000 Ceralpha units/kg of DMI was fed to lactating cattle. Likewise, Tricarico et al. (2007), who used a similar source of enzyme in growing heifers (activity of 950 dextrinizing units/kg of DMI), observed increases in DMI, especially during the first $28 \mathrm{~d}$ of their experiment. In several studies with lactating cows, however, DMI was either unaltered [662 dextrinizing units/kg of DMI (DeFrain et al., 2005); 311-332 KNU/kg of DMI (Weiss et al., 2011)] or was decreased (370 KNU/kg of DMI; Gencoglu et al., 2010) by dietary amylase. Differences in methodology used to evaluate enzyme activity (KNU vs. Ceralpha units vs. dextrinizing units) make it difficult to assess whether differences in enzyme activity explain the heterogeneous responses to enzymes, but even those studies with similar measures of enzyme activity generated variable responses. Dietary carbohydrate profiles differed widely across these studies, which may have contributed to the heterogeneous responses to amylase treatment. In addition, all diets in the current study were formulated to be low in starch content and relatively high in NDF content, largely from forage. High NDF content in rations for lactating cattle causes a physical fill that limits DMI (Qiu et al., 2003; Kendall et al., 2009; Weiss et al., 2011), which likely limited DMI in the current study. However, if sugar or exogenous amylase, or both, enhances the rate of NDF degradation, this would be expected to have the most positive effect on DMI when ruminal fill is the primary constraint.

We hypothesized that amylase affects ruminal fermentation by providing sugar substrate to nonamylolytic bacteria (e.g., cellulolytic species), and that its effect may be muted in a diet containing a relatively high concentration of free sugar. This hypothesis was not supported by our results, however, as we observed no significant interactions of amylase and sucrose. Weiss et al. (2011), in contrast, were able to detect some interactions of dietary starch concentration and amylase supplementation, suggesting that amylase enhanced total-tract nutrient digestibility when used in a $25 \%$ starch diet but not in a $31 \%$ starch diet. The implications of this finding were limited, though; in the production portion of the study, they only evaluated the effect of the enzyme combined with the low-starch diet (Weiss et al., 2011).

In some studies, the addition of exogenous amylase to diets with moderate starch concentrations (26-27\%) increased milk production (Tricarico et al., 2005; Klingerman et al., 2009). In the current study, however, the inclusion of amylase did not affect milk production, which is consistent with other studies that used exogenous amylase in low-starch rations. Weiss et al. (2011) and Ferraretto et al. (2011) reported no effect on milk yield, and McCarthy et al. (2013) reported a tendency for decreased milk production in cows supplemented with amylase (activity of $351 \mathrm{KNU} / \mathrm{kg}$ ). Some research has indicated that dietary amylase can improve the feed efficiency of lactating cows (Ferraretto et al., 2011), although others did not find differences in feed efficiency when amylase was included in low-starch diets (Weiss et al., 2011; McCarthy et al., 2013).

In the current trial, the diets that included amylase appeared to have higher analyzed sugar content $(0.2$ to $0.5 \%$ ) than the treatments that lacked the enzyme, suggesting enzyme activity during feed storage. This outcome did not agree with Weiss et al. (2011), who reported that amylase did not provide more sugar at the feed level, but coincided with Ferraretto et al. (2011), who reported higher sugar content in diets with added amylase.

The lack of response to sugar supplementation in the current study may be attributable to one factor that has received little attention with respect to feeding sugar to ruminants. Evidence exists that some bacteria and protozoa store sugars in the form of glycogen, thereby temporarily slowing fermentation acid production (Lou et al., 1997; Hall and Weimer, 2007; Penner and Oba, 2009). Some bacterial species (e.g., Prevotella bryantii) are known to ferment glycogen to acetate and succinate during starvation situations (Lou et al., 1997). The stored resources in the form of glycogen are, therefore, slowly metabolized to generate VFA. If this scenario is common, then VFA production from sugars may be more stable than is typically thought and would be less likely to influence microbial populations in the rumen in the absence of dramatic changes in feed accessibility. 


\section{CONCLUSIONS}

In contrast to previous work in which exogenous amylase significantly improved the feed efficiency of cows fed low-starch diets, we did not observe any significant effects of amylase, sucrose, or their interaction on intake, productivity, body condition, or feed efficiency of mid-lactation cows fed low-starch, high-fiber diets. Nevertheless, the small numeric increases in feed efficiency with amylase and sucrose treatments were consistent with previously observed improvements in fiber digestibility in response to similar treatments. Based on feed efficiency responses, our results hint at the conclusion that amylase may not be as advantageous in diets that are already high in sugar content. The inconsistencies between our findings and those of some previous studies highlight the fact that some interactions of amylase with animal or dietary factors remain unexplained. The mechanistic effects and potential interactions of amylase and sucrose may be worth evaluating at the ruminal level. Examination of the effects of such treatments on the rumen microbial ecosystem, ruminal $\mathrm{pH}$, and the kinetics of fiber degradation may provide a more precise understanding of the modes of action for these supplements.

\section{REFERENCES}

AOAC International. 2000. Official Methods of Analysis. 17th ed. AOAC International, Arlington, VA.

Bowman, G. R., K. A. Beauchemin, and J. A. Shelford. 2002. The proportion of the diet to which fibrolytic enzymes are added affects nutrient digestion by lactating dairy cows. J. Dairy Sci. 85:3420-3429.

Bradford, B. J., and C. R. Mullins. 2012. Invited review: Strategies for promoting productivity and health of dairy cattle by feeding nonforage fiber sources. J. Dairy Sci. 95:4735-4746.

Broderick, G. A., N. D. Luchini, S. M. Reynal, G. A. Varga, and V. A. Ishler. 2008. Effect on production of replacing dietary starch with sucrose in lactating dairy cows. J. Dairy Sci. 91:4801-4810.

Broderick, G. A., and W. J. Radloff. 2004. Effect of molasses supplementation on the production of lactating dairy cows fed diets based on alfalfa and corn silage. J. Dairy Sci. 87:2997-3009.

Cabrita, A. R. J., R. J. B. Bessa, S. P. Alves, R. J. Dewhurst, and A. J. M. Fonseca. 2007. Effects of dietary protein and starch on intake, milk production, and milk fatty acid profiles of dairy cows fed corn silage-based diets. J. Dairy Sci. 90:1429-1439.

Dairy Records Management Systems. 2013. DHI Glossary. Accessed Jun. 17, 2013. http://www.drms.org/PDF/materials/glossary.pdf.

DeFrain, J. M., A. R. Hippen, K. F. Kalscheur, and J. M. Tricarico. 2005. Effects of dietary $\alpha$-amylase on metabolism and performance of transition dairy cows. J. Dairy Sci. 88:4405-4413.

DeVries, T. J., and R. M. Gill. 2012. Adding liquid feed to a total mixed ration reduces feed sorting behavior and improves productivity of lactating dairy cows. J. Dairy Sci. 95:2648-2655.

Ellis, J. L., J. Dijkstra, A. Bannink, A. J. Parsons, S. Rasmussen, G. R. Edwards, E. Kebreab, and J. France. 2011. The effect of high-sugar grass on predicted nitrogen excretion and milk yield simulated using a dynamic model. J. Dairy Sci. 94:3105-3118.

Ferraretto, L. F., R. D. Shaver, M. Espineira, H. Gencoglu, and S. J. Bertics. 2011. Influence of a reduced-starch diet with or without exogenous amylase on lactation performance by dairy cows. J. Dairy Sci. 94:1490-1499.
Firkins, J. 2010. Addition of sugars to dairy rations. Page 91-105 in Proc. Tri-State Dairy Nutrition Conference. The Ohio State University, Columbus.

Gencoglu, H., R. D. Shaver, W. Steinberg, J. Ensink, L. F. Ferraretto, S. J. Bertics, J. C. Lopes, and M. S. Akins. 2010. Effect of feeding a reduced-starch diet with or without amylase addition on lactation performance in dairy cows. J. Dairy Sci. 93:723-732.

Golder, H. M., P. Celi, A. R. Rabiee, C. Heuer, E. Bramley, D. W. Miller, R. King, and I. J. Lean. 2012. Effects of grain, fructose, and histidine on ruminal $\mathrm{pH}$ and fermentation products during an induced subacute acidosis protocol. J. Dairy Sci. 95:1971-1982.

Hall, M. B., and P. J. Weimer. 2007. Sucrose concentration alters fermentation kinetics, products, and carbon fates during in vitro fermentation with mixed ruminal microbes. J. Anim. Sci. $85: 1467-1478$.

Huntington, G. B. 1997. Starch utilization by ruminants: From basics to the bunk. J. Anim. Sci. 75:852-867.

Jung, S., and K. Vogel. 2008. Determination of Ronozyme RumiStar alpha-amylase activity in feed and per samples. DSM Nutritional Products Ltd. Regulatory Report 2500706. DSM Nutritional Products Ltd., Basel, Switzerland.

Kendall, C., C. Leonardi, P. C. Hoffman, and D. K. Combs. 2009. Intake and milk production of cows fed diets that differed in dietary neutral detergent fiber and neutral detergent fiber digestibility. J. Dairy Sci. 92:313-323.

Klingerman, C. M., W. Hu, E. E. McDonell, M. C. DerBedrosian, and L. Kung Jr. 2009. An evaluation of exogenous enzymes with amylolytic activity for dairy cows. J. Dairy Sci. 92:1050-1059.

Kononoff, P. J., A. J. Heinrichs, and D. R. Buckmaster. 2003. Modification of the Penn State forage and total mixed ration particle separator and the effects of moisture content on its measurements. J. Dairy Sci. 86:1858-1863.

Lammers, B. P., D. R. Buckmaster, and A. J. Heinrichs. 1996. A simple method for the analysis of particle sizes of forages and total mixed rations. J. Dairy Sci. 79:922-928.

Lane, J. H., and L. Eynon. 1923. Determination of reducing sugars by means of Fehling's solution with methylene blue as internal indicator. J. Soc. Chem. Ind. Trans. 42:32-36.

Lemosquet, S., G. Raggio, G. E. Lobley, H. Rulquin, J. Guinard-Flament, and H. Lapierre. 2009. Whole-body glucose metabolism and mammary energetic nutrient metabolism in lactating dairy cows receiving digestive infusions of casein and propionic acid. J. Dairy Sci. 92:6068-6082.

Lou, J., K. A. Dawson, and H. J. Strobel. 1997. Glycogen biosynthesis via UDP-glucose in the ruminal bacterium Prevotella bryantii B1(4). Appl. Environ. Microbiol. 63:4355-4359.

Martel, C. A., E. C. Titgemeyer, L. K. Mamedova, and B. J. Bradford. 2011. Dietary molasses increases ruminal $\mathrm{pH}$ and enhances ruminal biohydrogenation during milk fat depression. J. Dairy Sci. 94:3995-4004.

Masuda, Y., S. Kondo, M. Shimojo, and I. Goto. 1999. Effect of sugarbeet pulp on fiber degradation of grass hay in the rumen of goats. Asian-australas. J. Anim. Sci. 12:186-188.

McCarthy, M. M., M. A. Engstrom, E. Azem, and T. F. Gressley. 2013. The effect of an exogenous amylase on performance and total-tract digestibility in lactating dairy cows fed a high-byproduct diet. J. Dairy Sci. 96:3075-3084.

McDougall, E. I. 1948. Studies on ruminant saliva. Biochem. J. 43:99-109.

Miller, J. K., B. R. Moss, R. F. Hall, and G. M. Gorman. 1969. Evaluation of methods for introducing materials directly into the abomasum of yearling cattle. J. Dairy Sci. 52:1643-1649.

Miron, J., E. Yosef, D. Ben-Ghedalia, L. E. Chase, D. E. Bauman, and R. Solomon. 2002. Digestibility by dairy cows of monosaccharide constituents in total mixed rations containing citrus pulp. J. Dairy Sci. 85:89-94.

Nafikov, R. A., and D. C. Beitz. 2007. Carbohydrate and lipid metabolism in farm animals. J. Nutr. 137:702-705.

NRC. 2001. Nutrient Requirements of Dairy Cattle. 7th rev. ed. Natl. Acad. Sci., Washington, DC. 
Oba, M. 2011. Review: Effects of feeding sugars on productivity of lactating dairy cows. Can. J. Anim. Sci. 91:37-46.

Penner, G. B., K. A. Beauchemin, and T. Mutsvangwa. 2007. Severity of ruminal acidosis in primiparous Holstein cows during the periparturient period. J. Dairy Sci. 90:365-375.

Penner, G. B., and M. Oba. 2009. Increasing dietary sugar concentration may improve dry matter intake, ruminal fermentation, and productivity of dairy cows in the postpartum phase of the transition period. J. Dairy Sci. 92:3341-3353.

Qiu, X., M. L. Eastridge, and Z. Wang. 2003. Effects of corn silage hybrid and dietary concentration of forage NDF on digestibility and performance by dairy cows. J. Dairy Sci. 86:3667-3674.

Ranathunga, S. D., K. F. Kalscheur, A. R. Hippen, and D. J. Schingoethe. 2010. Replacement of starch from corn with nonforage fiber from distillers grains and soyhulls in diets of lactating dairy cows. J. Dairy Sci. 93:1086-1097.

Tricarico, J. M., M. D. Abney, M. L. Galyean, J. D. Rivera, K. C. Hanson, K. R. McLeod, and D. L. Harmon. 2007. Effects of a dietary Aspergillus oryzae extract containing $\alpha$-amylase activity on performance and carcass characteristics of finishing beef cattle. J. Anim. Sci. 85:802-811.

Tricarico, J. M., J. D. Johnston, K. A. Dawson, K. C. Hanson, K. R. McLeod, and D. L. Harmon. 2005. The effect of an Aspergillus oryzae extract containing $\alpha$-amylase activity on ruminal fermentation and milk production in lactating Holstein cows. Anim. Sci $81: 365-374$.

Tyrrell, H. F., and J. T. Reid. 1965. Prediction of the energy value of cow's milk. J. Dairy Sci. 48:1215-1223.

Van Soest, P. J., J. B. Robertson, and B. A. Lewis. 1991. Methods for dietary fiber, neutral detergent fiber, and nonstarch polysaccharides in relation to animal nutrition. J. Dairy Sci. 74:3583-3597.

Weiss, W. P., J. M. Pinos-Rodríguez, and M. T. Socha. 2010. Effects of feeding supplemental organic iron to late gestation and early lactation dairy cows. J. Dairy Sci. 93:2153-2160.

Weiss, W. P., W. Steinberg, and M. A. Engstrom. 2011. Milk production and nutrient digestibility by dairy cows when fed exogenous amylase with coarsely ground dry corn. J. Dairy Sci. 94:24922499.

Wildman, E. E., G. M. Jones, P. E. Wagner, R. L. Boman, H. F. Troutt Jr., and T. N. Lesch. 1982. A dairy cow body condition scoring system and its relationship to selected production characteristics. J. Dairy Sci. 65:495-501.

Zebeli, Q.. J. R. Aschenbach, M. Tafaj, J. Boguhn, B. N. Ametaj, and W. Drochner. 2012. Invited review: Role of physically effective fiber and estimation of dietary fiber adequacy in high-producing dairy cattle. J. Dairy Sci. 95:1041-1056. 